\title{
How to manage the cumulative flood safety of catchment dams
}

\author{
John D Pisaniello* \\ Sustainable Law and Engineering Group, Centre for Accounting, Governance and Sustainability, School of Commerce, \\ University of South Australia, Way Lee Building, City West Campus, North Terrace, Adelaide SA 5000
}

\begin{abstract}
Dam safety is a significant issue being taken seriously worldwide. However, in Australia, although much attention is being devoted to the medium- to large-scale dams, minimal attention is being paid to the serious potential problems associated with smaller dams, particularly the potential cumulative safety threats they pose in catchments. This paper establishes the significance of this problem and reviews various Australian policies, including consideration of evidence from past research, to identify the potentially more effective policies with respect to smaller dams/cumulative safety assurance. New 'case studies' research that recently tested the effectiveness and coverage of the "strong" dam-safety policy of New South Wales (NSW) is then reported. The case studies comprised 2 samples of 10 hazardous private reservoirs investigated for spillway adequacy in line with state-of-the-art practice: one sample comprised dams supervised under the NSW policy, while the other sample comprised only non-supervised dams. The case studies show the potential effectiveness of strong policy, but also the importance of registering all dams and the need for some form of supervision of even small dams due to either their individual or cumulative hazard potential. The State of Tasmania provides a 'model' on how this can be best achieved in line with international best-practice, and this recently became the focus of a comprehensive study. This study involved strategic consideration and assessment of policy responses to the varying issues associated with small-dam safety and practical feedback from key policy actors. The results of this study are also reported here to provide guidance to any other jurisdiction world-wide needing to manage numerous small dams posing cumulative safety threats in catchments.
\end{abstract}

Keywords: catchment dams, flood safety, cascade failure, cumulative risks, model policy

\section{Introduction}

In Australia, a clear problem exists with private dam safety: Australia has a large number of relatively small, privately owned dams (farm dams especially, numbering approximately 480000 (Price et al., 2003)) and those which have failed number in the thousands. The Australian National Committee on Large Dams (ANCOLD) in 1992 estimated that $23 \%$ of farm dams in NSW had failed (ANCOLD, 1992). In Tasmania around 500 of the 8000 registered dams are of significant potential safety risk (DPIWE, 2005, p.21; Ditchfield, 2008). In Victoria 800 of the 170000 farm dams are hazardous (Murley, 1987), and Lewis and Harrison (2002) reported that at least 10 significant failures have occurred in Victoria in the past decade. The policy responses of various States to these farm-dam safety threats are reviewed here.

One of the main concerns is that most private dams are deprived of necessary maintenance and upgrading and downstream communities are placed at risk. This problem was demonstrated by recent case studies undertaken in the 'still' policy-absent State of South Australia and the 'now' policy-driven State of Victoria (Pisaniello and McKay, 2005). These case studies showed that giving only more time, awareness and encouragement to landholders addresses

\footnotetext{
* To whom all correspondence should be addressed.

疋 +61 88302 0031; fax: +61 88302 0992; e-mail: John.Pisaniello@unisa.edu.au

Received 15 September 2008; accepted in revised form 25 April 2009
}

the problem to a minimal extent - adequate assurance can only be provided through appropriate policy which requires the backing of law-makers, and effective and efficient administration of laws is also vital.

In this paper, the significance of this small-dam safety problem, particularly in relation to the cumulative threats they pose within larger catchments, is established. NSW has had a specific Dams Safety Act in place since 1978 which represents 'strong' dam-safety assurance policy (Pisaniello and McKay, 1998). This strong policy was recently tested for its effectiveness and coverage, particularly in relation to smaller yet hazardous dams. The results are reported here to provide comparative policy guidance. Tasmania recently implemented policy on private dam safety which effectively deals with all the issues raised by Pisaniello and McKay (2005) as barriers to achieving private dam-safety programmes in other states. The Tasmanian policy therefore became the focus of a comprehensive study. This study involved strategic consideration and assessment of policy responses to the varying issues associated with small-dam safety and practical feedback from key policy actors. The results of this study are also reported here to provide lessons and guidance to any other jurisdiction world-wide: any jurisdiction needing to manage numerous small dams that pose either significant individual or cumulative threats in catchments.

\section{Dam-safety management in Australia and the small-dam safety problem}

In Australia, as in most countries, owner obligation exists under common law to take reasonable care of dams according 
to current prevailing standards. Hence, owners should review their dams, and take appropriate action where necessary, in order to minimise the risk of failure and avoid liability for possible consequences of failure (McKay and Pisaniello, 1995).

\section{How dam safety is managed in Australia}

Most Australian Government dam-owning agencies have assumed the responsibility of evaluating public dams in terms of risk in accordance with current guidelines, and subsequently have either undertaken or are implementing appropriate action, at massive costs, to reduce the risks to modern acceptable standards. For example, in NSW safety upgrades on Pindari and Warragamba Dams were recently completed at a cost of AU\$68.8 m. (ZAR442 m.) and AU\$100 m. (ZAR643 m.) respectively (NSW Department of Land and Water Conservation, 1995; NSW DSC, 2003). In South Australia, extensive safety studies and subsequent upgrading have recently been commissioned for most public dams, e.g.: Mount Bold Reservoir (Daniell and Hill, 1993), Kangaroo Creek Dam (Lange Dames Campbell (SA) (Pty.) Ltd. and Snowy Mountains Engineering Corporation, 1995), and Happy Valley Reservoir (BC Tonkin and Associates, 1997). However, as reported in Pisaniello and McKay (2005), there is a policy vacuum in mainland Australia on private dam-safety policy, except partially in NSW (Dams Safety Act, 1978), Victoria (Water Act, 1989) and Queensland (Water Act, 2000), but even their policies are not pervasive. That is, they only address the problems associated with hazardous dams, usually the larger, more significant onstream dams, without giving due consideration to the problems associated with the multitude of smaller off-stream catchment dams nor the supervision over the management of these structures. In contrast, Tasmania has addressed these problems and a more detailed discussion on this 'model' policy is provided below (see section titled: Dam-safety assurance in Tasmania: A 'model' policy).

In Victoria an attempt has recently been made to address this 'smaller dams' safety problem by incorporating amendments to the Water Act 1989, see Pisaniello and McKay (2005). However, research has demonstrated that while the recent policy and law reforms are a step in the right direction for Victoria, efficient and effective administration of the policy is just as important (Pisaniello and McKay, 2005).

In Queensland, key water allocation provisions have been incorporated into the Water Act 2000 together with dam-safety provisions that target 'referable' dams. Unfortunately, the definition of 'referable' dams, generally, only catches ones higher than $8 \mathrm{~m}$ and with $250 \mathrm{M} \ell$ capacity or more. Based on Pisaniello and Mckay (1998), this is too lenient compared to world wide standards. Hence, many hazardous smaller offstream dams may go unsupervised in Queensland.

In NSW, any issues of dam safety are left entirely up to the Dams Safety Act 1978 and the Dams Safety Committee (DSC) constituted under it. The Dams Safety Act represents best practice legislation when compared to international standards in terms of the sort of dams that should be prescribed under the Act and the levels of supervision and responsibility imposed upon dam owners (Pisaniello and McKay, 1998; Bradlow et al., 2002; further details also provided later in this paper). Unfortunately the Dams Safety Act does not appear to provide for an adequate register of all dams (including small ones) in the State, nor does it provide for an adequate budget to enable the DSC to supervise more dams than are already prescribed. Hence, many of the smaller off-stream dams which nevertheless pose significant hazard downstream, either individually or cumulatively, may go unnoticed. This is demonstrated by recent case studies, which are reported later in this paper (see section headed: Spillway adequacy case studies in NSW).

\section{The significance of the small-dam safety problem}

As discussed above, Australia has many small, privately owned dams that are poorly maintained, thousands of which have failed. At the same time more farm dams have been built to capture water as changes to the water allocation policies in Australia have been mooted since the early 1990s (McKay, 2001). Studies have shown that in general dams fail more so by overtopping due to inadequate spillway capacity: this failure mode represents around $40 \%$ of all recorded failures worldwide (Foster et al, 2000, p.1005) and embankment dams (which typifies private dams) are the most susceptible representing 70\% of these (Pisaniello, 1997; ANCOLD, 1992; 1995).

While failures of large dams are generally more spectacular than those of smaller dams and receive much more attention, small-dam failures, particularly those of privately-owned farm dams, occur far more frequently (also supported by Lewis and Harrison, 2002). Therefore, in many cases, the total annual cost of small-dam failures is more serious than the rare failures of large dams. Also, past events have occurred where failures of relatively small dams have caused quite disastrous consequences. For example, in China the Shimantan and Banqiao Dams failed in 1975 as a result of the cumulative failure of 60 smaller upstream dams, resulting in the death of 230000 people (Si and Quing, 1998). In Italy, the Stava Dam near Trento failed in 1985 and while releasing only $180 \mathrm{M \ell}$ of tailings material, it killed 268 people and caused serious environmental impact (Engels, 2005). In the United States, the Kelly Barnes Lake Dam, only 8 m high, failed in 1977 killing a total of 39 people; and the Lake Lawn Dam in Colorado which was also $8 \mathrm{~m}$ high and stored only $830 \mathrm{M} \ell$, failed in 1982 drowning 3 people and causing US\$31 million in damage despite warnings and evacuation (Hiser \& McDonald, 1989). Also in the US, the Evans and Lockwood dams, which were only around $5 \mathrm{~m}$ high and held only $89 \mathrm{M} \ell$ and $39 \mathrm{M} \ell$ of water respectively, both overtopped and failed in a cascade manner in 1989 killing 2 people (Graham, 1999).

A study by Graham (1999) of dam failures in the US resulting in fatalities from 1960 to 1998, found that the failure of dams less than $15 \mathrm{~m}$ high (which is the typical height range of smaller dams) caused $88 \%$ of the deaths. The study also found that the failure of dams less than $6 \mathrm{~m}$ high (i.e. very small dams) caused $2 \%$ of the deaths. These past events demonstrate that without appropriate design, construction, maintenance and surveillance, poorly managed small dams can pose significant individual and cumulative threats, and can cause considerable human, property and environmental losses to the community.

This paper looks to address 2 main concerns with small dams in Australia in line with international experience and practice as follows.

\section{Concern 1: Inadequate dam construction and maintenance}

Many private dams are unsafe due to improper design, particularly flood capability design, and general lack of review and 
maintenance: failure can result which can impact badly on the immediate downstream inundation zone. This concern arises because:

- Most landholders hire contractors to build their dams: contractors that are typically not properly trained or skilled in the engineering design of dams

- Dam owners are generally complacent with dam surveillance, review and maintenance

- The typical probabilities required for design floods are beyond the average farmer's comprehension.

Pisaniello and McKay (2005) and the NSW case studies reported below validate this concern.

\section{Concern 2: Potential impact of cumulative failure of many small dams}

The lack of safety of the small dams individually can lead to cumulative failure during medium to large floods which can produce a flood with severe downstream consequences. This was demonstrated by the Shimantan and Banqiao Dam failures in China and the Evans and Lockwood Dam failures in the US discussed above. It was also demonstrated in the Adelaide Hills of South Australia in 1992- extreme weather delivering rainfall events of 1-in-60 years, resulted in widespread damaging floods from 'farm dam failures [that] provided additional problems and contributed to the overall damage costs' (Harrison, 1992).

It was also found to be of concern in a flood study of the large public Kangaroo Creek Dam in the Torrens catchment of South Australia (LDC \& SMEC, 1995). The modelling procedure adopted in the River Torrens study was reported by Kazarovski (1996). The study found that the peak inflow to Kangaroo Creek Dam would increase fourfold and cause it to fail assuming all the small dams in the catchment failed at the same time in an extreme design flood event of only 1-in-200 years, compared to the flow estimated if the dams remained intact. The cumulative failure of these small dams was a reasonable assumption given that later Pisaniello and McKay (2005) found that most small dams in South Eastern Australia would not withstand the 1-in-100 years design flood event. The River Torrens study thus recognised the need for 'controlling the standard of construction of farm dams and their spillways' (LDC and SMEC, 1995).

Added is the problem that global warming is causing extreme flood events to become more probable (UN IPCC, 2007); hence the likelihood of disastrous, cumulative-style dam failures in Australia increases even more.

If small dams are located upstream with potential to cause cascade failure of larger more hazardous dams, then ANCOLD (2000a, p.10) warns that 'the combined effect of multiple dam failures should be the basis of the hazard category of the upper dams.' This guideline interpreted strictly, and together with the findings of LDC and SMEC (1995) and Kazarovski (1996), would deem that in certain circumstances, all small dams in a catchment upstream of a large, high-hazard public reservoir should also be treated as high hazard (due to their potential cumulative failure impact), and should therefore each individually meet the same design standard. This area does require further research into the kind of small-dam populations and overall storage volumes that are critical for different catchment circumstances. However, it has nevertheless become clear that all small dams in catchments of large public dams should be registered and at least controlled for spillway adequacy regard- less of their size and individual hazard potential. They should be mandated to at least meet ANCOLD's minimum fall-back design criteria for low or significant hazard dams (i.e. 1 in 100 to 1 in 1000 years design flood), and upgraded to a higher standard when clearly warranted in cumulative or cascade failure scenarios.

Internationally, many countries, including Canada, Finland, Portugal, South Africa, the United Kingdom and the US, have recently adopted safety regulation and surveillance acts in an attempt to ensure the safety of both public and private dams. Pisaniello and McKay (1998 and 2003) provide more detailed comparative analyses of the varying criteria used in these countries to regulate dams, including size class, hazard potential, surveillance levels and spillway adequacy standards. The analyses by Pisaniello and McKay (1998 and 2003) demonstrate that certain countries have regulated dams as small as $1.8 \mathrm{~m}$ high (Michigan, USA) and with a minimum storage capacity of $25 \mathrm{M} \ell$ (UK) regardless of dam hazard potential, hence recognising the need to assure the safety of even the smallest of dams. In Australia, Tasmania is the only state thus far to acknowledge that, even small dams need to be supervised in such a way, as demonstrated below (see section titled: Damsafety assurance in Tasmania: A 'model' policy).

\section{Spillway adequacy case studies in NSW - testing a 'strong' dam-safety assurance policy and its coverage of regulated dams}

As discussed above, dam safety in NSW is regulated under the Dams Safety Act 1978 and supervised by the DSC. The Committee, consisting of 8 part-time members, is independent of any Government agencies which construct or own dams. The Committee is funded by the State Government and currently operates on a small annual budget of around AU\$1 000000 (ZAR6 430 000) (NSW DSC, 2007). The Committee has the responsibility for setting standards and monitoring their observance for prescribed dams - its standards are based on Australian guidelines developed with a background of international practice (NSW DSC, 2007). Prescribed dams are those listed in Schedule 1 of the Act which is progressively amended by additions or deletions. Dams are prescribed on the recommendation of the Committee. A dam is normally prescribed if it is greater than $15 \mathrm{~m}$ in height or if it is a smaller dam with either a high or significant hazard rating - in general, dams with a wall height of less than $5 \mathrm{~m}$ are only prescribed if a high hazard potential is posed (NSW DSC, 1993). In 2007 there were 334 prescribed dams in NSW, with only around 100 being privately owned (NSW DSC, 2007, p.36). Hence, many smaller off-stream dams which are hazardous may only be prescribed if and when they come to the attention of the DSC, otherwise they go unnoticed.

In order to independently test the effectiveness of this system, 2 case studies were recently undertaken as part of an Australian Research Council Discovery Project.

\section{Case-study procedure}

The case studies involved determining the modern flood capabilities of 2 samples each comprising 10 hazardous private reservoirs: the first sample consisted of prescribed embankment 'farm-type' dams which were supervised by the DSC, while the second sample consisted of dams that were not under the supervision of the DSC. A brief outline of the procedure is as follows: 
- The 10 'farm-type' dams in the DSC-supervised sample were randomly selected from the 100 or so privately owned dams contained in Schedule 1 of the Act. The fact that they were prescribed deemed them to be hazardous in nature. The 10 dams in the non-supervised sample were selected randomly from aerial photography and topographic maps on the basis that they be 'referable' in size and either 'significant' or 'high hazard' in accordance with ANCOLD (2000a and 2000b) guidelines. The criteria used by ANCOLD for its 3 main hazard classifications can be summarised as follows:

- High Hazard Potential - dam failure will endanger many lives in a downstream community and will cause extensive damage

- Significant Hazard Potential -failure may endanger some lives and will cause extensive damage

- Low Hazard Potential - failure poses minimal risk to life and will cause limited damage

- Each of the dam sites in the non-supervised sample was visited and spillway/embankment sizes were measured using appropriate survey equipment. Only some of the dam sites in the DSC-supervised sample were visited as in most cases spillway/embankment sizes could be readily obtained from independent engineering reports and data contained in the DSC files. Catchment and reservoir areas were determined from 1:25000 scale topographic maps and aerial photos.

- The sample dams were all embankment-type structures and had typical spillways that were free flowing and weir-type in nature. The main physical characteristics of each dam are presented in Tables 1 and 2. In summary, the maximum wall heights of the dams ranged from $4 \mathrm{~m}$ to $23 \mathrm{~m}$ for the DSC-supervised dams and $6.5 \mathrm{~m}$ to $18.5 \mathrm{~m}$ for the nonsupervised dams; their storage capacities ranged from $60 \mathrm{M} \ell$ to $1450 \mathrm{M} \ell$ for the DSC-supervised dams and $50 \mathrm{M} \ell$ to $900 \mathrm{M} \ell$ for the non-supervised dams; and the size of their catchments ranged from $0.2 \mathrm{~km}^{2}$ to $20 \mathrm{~km}^{2}$ for the DSC-supervised dams and from $0.2 \mathrm{~km}^{2}$ to $3.5 \mathrm{~km}^{2}$ for the non-supervised dams.

- The regionalised flood capability design/review procedure, described in Pisaniello and McKay (2003 and 2005), was used to determine the dam crest flood (DCF) capability of each dam, being the flood which, when routed through the reservoir results in a peak storage level equal to the lowest elevation on the non-overflow crest (as recommended by ANCOLD, 2000b for embankment dams). The procedure enabled the DCF of each dam to be determined as an annual exceedance probability (AEP), which is presented as 1/AEP in years in Tables 1 and 2. It should be noted that the regionalised procedure had been previously developed based on Australian best-practice catchment analysis, calibration and modelling, flood hydrology and reservoir hydraulics, all in line with IEAust (1999). The procedure is simple, yet scientifically acceptable, and was specifically developed for small dams on small catchments to promote consistency and uniform standards. It can be used to either review or design the flood capability of such dams for all possible design flood events up to the Probable Maximum Flood (PMF). For a full description of the primary development of this technology, see Pisaniello et al. (1999); for development in NSW specifically, see Pisaniello and McKay (2004).

The DCF capability of each dam was determined for both an upper bound and lower bound 'start' storage level case for the non-supervised dams only:

- Upper bound case - initial storage level assumed 100\% full

- $\quad$ Lower bound case - initial storage level assumed 33\% full.

The lower bound case is highly non-conservative, and was checked for the non-supervised dams to minimise uncertainty. For the DSC-supervised dams, the most conservative upper bound case was imposed, and the dams were found to all pass the requisite standard; hence, there was no need to check the lower bound case.

The case-study results are presented in the following section (see Tables 1 and 2).

\section{Case-study results and analysis}

The results of the case studies were analysed by comparing them against ANCOLD criteria as illustrated in Tables 1 and 2 for the DSC-supervised and the non-supervised sample respectively.

ANCOLD (2000b) guidelines recommend that unless nor-

\begin{tabular}{|c|c|c|c|c|c|c|c|}
\hline \multicolumn{8}{|c|}{$\begin{array}{c}\text { TABLE } 1 \\
\text { Comparison of NSW flood capability results with ANCOLD (2000a \& 2000b) Guidelines: DSC-supervised } \\
\text { dams sample }\end{array}$} \\
\hline $\begin{array}{l}\text { Dam } \\
\text { No. }\end{array}$ & $\begin{array}{c}\text { Dam height } \\
\text { (m) }\end{array}$ & $\begin{array}{l}\text { Storage } \\
\text { capacity when } \\
\text { full } \\
\text { (Me) }\end{array}$ & $\begin{array}{c}\text { Catchment } \\
\text { area } \\
\left(\mathbf{k m}^{2}\right)\end{array}$ & $\begin{array}{c}\text { Minimum } \\
\text { hazard rating } \\
\text { (High/Sig.) }\end{array}$ & $\begin{array}{l}\text { DCF if } 100 \% \\
\text { full } \\
1 / \text { AEP } \\
\text { (years) }\end{array}$ & $\begin{array}{c}\text { ANCOLD } \\
\text { guidelines } \\
\text { DCF range 1/ } \\
\text { AEP } \\
\text { (years) }\end{array}$ & $\begin{array}{c}\text { Acceptable } \\
\text { under } \\
\text { ANCOLD } \\
\text { guidelines? } \\
\text { (Yes/No) }\end{array}$ \\
\hline 1 & 23 & 1450 & 15 & Sig. & 1100 & $10000-1000$ & Yes \\
\hline 2 & 6.1 & 174 & 2.1 & Sig. & 475000 & $10000-1000$ & Yes \\
\hline 3 & 17.5 & 1200 & 20 & Sig. & 40000 & $10000-1000$ & Yes \\
\hline 4 & 5 & 95 & 3.5 & High & 12500 & PMF-10 000 & Yes \\
\hline 5 & 4.5 & 60 & 0.8 & High & 310000 & PMF-10 000 & Yes \\
\hline 6 & 7 & 65 & 3.2 & Sig. & 55000 & $10000-1000$ & Yes \\
\hline 7 & 12 & 250 & 0.3 & Sig. & 6000000 & $10000-1000$ & Yes \\
\hline 8 & 4 & 135 & 14 & Sig. & 1050 & $10000-1000$ & Yes \\
\hline 9 & 5 & 380 & 0.2 & High & 10000000 & PMF-10 000 & Yes \\
\hline 10 & 14 & 270 & 0.2 & High & 10000000 & PMF-10 000 & Yes \\
\hline
\end{tabular}




\begin{tabular}{|c|c|c|c|c|c|c|c|c|c|}
\hline \multicolumn{10}{|c|}{$\begin{array}{rr}\text { TABLE } 2 \\
\text { Comparison of NSW flood capability results wit }\end{array}$} \\
\hline $\begin{array}{l}\text { Dam } \\
\text { No. }\end{array}$ & $\begin{array}{l}\text { Dam } \\
\text { height } \\
(\mathrm{m})\end{array}$ & $\begin{array}{c}\text { Storage } \\
\text { capacity } \\
\text { when full } \\
\text { (Me) }\end{array}$ & $\begin{array}{c}\text { Catchment } \\
\text { area } \\
\left(\mathbf{k m}^{2}\right)\end{array}$ & $\begin{array}{l}\text { Minimum } \\
\text { hazard } \\
\text { rating } \\
\text { (High/Sig.) }\end{array}$ & $\begin{array}{c}\text { DCF if } \\
100 \% \text { full } \\
1 / \mathrm{AEP} \\
\text { (years) }\end{array}$ & $\begin{array}{c}\text { DCF if } \\
33 \% \\
\text { full } 1 / A E P \\
\text { (years) }\end{array}$ & $\begin{array}{l}\text { ANCOLD } \\
\text { guidelines } \\
\text { DCF range } \\
\text { 1/AEP } \\
\text { (years) }\end{array}$ & $\begin{array}{c}\text { Acceptable } \\
\text { under non- } \\
\text { conservative } \\
\text { assumption } \\
\text { that dam is } \\
\text { always } 33 \% \\
\text { full? } \\
\text { (Yes/No) }\end{array}$ & $\begin{array}{c}\text { Acceptable } \\
\text { under ANCOLD } \\
\text { guidelines? } \\
\text { (Yes/No) }\end{array}$ \\
\hline 1 & 9.6 & 124 & 0.52 & High & 53000 & 1000000 & PMF-10 000 & Yes & Yes \\
\hline 2 & 9.2 & 73 & 0.29 & Sig. & 900 & 46000 & $10000-1000$ & Yes & No \\
\hline 3 & 8.0 & 60 & 0.40 & High & 2500 & 37000 & PMF-10 000 & Yes & No \\
\hline 4 & 6.5 & 50 & 0.20 & Sig. & 590 & 50000 & $10000-1000$ & Yes & No \\
\hline 5 & 18.5 & 900 & 1.25 & High & 100000 & 10000000 & PMF-10 000 & Yes & Yes \\
\hline 6 & 9 & 150 & 3.50 & Sig. & 10 & 80 & $10000-1000$ & No & No \\
\hline 7 & 6.9 & 64 & 0.20 & Sig. & 125 & 850 & $10000-1000$ & No & No \\
\hline 8 & 8 & 83 & 0.67 & Sig. & 500 & 4500 & $10000-1000$ & Yes & No \\
\hline 9 & 9 & 67 & 0.47 & Sig. & 80 & 900 & $10000-1000$ & No & No \\
\hline 10 & 8.2 & 55 & 0.24 & Sig. & 750 & 20000 & $10000-1000$ & Yes & No \\
\hline
\end{tabular}

mal operating conditions indicate otherwise, a 100\% full 'start' storage level should be assumed when assessing spillway flood capability of embankment dams. The comparisons in Tables 2 demonstrate that regardless of the 'start' storage level assumed, potentially hazardous private reservoirs with inadequate spillway capacities do exist in NSW. The risk of failure from overtopping is consistently unacceptable for $80 \%$ of the total non-supervised sample. At the same time, the flood capabilities of $30 \%$ of the non-supervised dams do not satisfy the required criteria even when the 'lower-bound' non-conservative assumption is applied (i.e. that the dam is always $33 \%$ full at the beginning of any storm). In contrast, and not surprisingly, $100 \%$ of the DSC-supervised sample met the necessary modern standard for spillway safety.

These results reinforce the fact that private dam owners, unless they are regulated and supervised, will not take action in terms of analysis and upgrading of their structures. The perfect results from the DSC-supervised sample demonstrate the effectiveness of a properly administered dam-safety assurance policy. However, at the same time, the results from the non-supervised sample demonstrate that without adequate register of all dams in NSW, and proper mechanisms in place for identifying all significant dams, many such dams can and do escape regulation and compliance. It is also clear that the DSC would need more funding to extend its supervisory remit, and hence, this may necessitate some 'user pays'.

\section{Dam-safety assurance in Tasmania: A 'model' policy}

Tasmania has over $30 \%$ of Australia's total water storage capacity, and in the past few years there has been a large expansion of storages for irrigation underway, to support the sustainable expansion of agricultural production (DPIWE, 2003 and 2005). Hence, the Tasmanian Government recognised the need to tighten legislative controls in order to ensure the safety of dams in Tasmania. This was achieved firstly in late 2002 by making amendments to the Water Management Act 1999 (Tas), and then in November the following year passing the Water Management (Safety of Dams)
Regulations 2003, which are now in operation across the State.

The legislation was introduced in line with the Tasmanian Government's policy to improve safety arrangements for the community and the environment. It was considered inadequate to solely rely on the non-statutory 'duty-of-care' principles to ensure that dams were maintained in a safe condition. The legislation was developed in close consultation with dam experts from government agencies, the Hydro and the mining industry, and with key stakeholder groups such as primary producers and local government. The Minister responsible pointed out that in developing the dam-safety legislative framework, the Government's objective had been to achieve the appropriate balance between, on the one hand, ensuring public and environmental protection and on the other, imposing restrictive and expensive requirements on dam builders and owners (DPIWE, 2003).

\section{Description of the dam-safety legislation}

The legislation provides for specific safety measures to be required for the design, construction and operation of all dams that hold 1 or more $\mathrm{M} \ell$ of water or waste, based on their hazard potential to the community, see Section 165A of the Water Management Act 1999 and Part 2 of the Water Management (Safety of Dams) Regulations 2003.

Essentially, under the Act all proposed new dams must obtain a permit (Part 8) and all existing dams have to be registered (Part 8A). The Act is administered by the Department of Primary Industries, Water and Environment (DPIWE), and an Assessment Committee constituted under the Act (see Section 138). It should be noted that DPIWE is now the Department of Primary Industries and Water (DPIW). The main role of the Assessment Committee is to assess all new dam permit applications. The Committee must consist of 6 members appointed by the Minister and nominated by various organisations in order to ensure a collective expertise in areas such as water resources, dams engineering and safety, integrated natural resource management and best practice environmental management (see Section 139). The permit process also requires public advertisement of any new dam 
proposals prior to any permit being granted (DPIW, 2008). This enables DPIW to hear and consider any objections to the proposal from the community, and also satisfies international best-practice 'community right to know' principles (Pisaniello and McKay, 1998). The ongoing safety of existing dams is supervised by the Minister and the Minister's delegates (primarily officers of DPIW).

Section $165 \mathrm{G}$ of the Act expressly imposes a duty on all dam owners to, so far as is reasonably practicable, maintain and operate their dams so as not to cause, or be likely to cause, material environmental harm or serious environmental harm or danger to any person or property. Part 8A of the Act gives wide powers to the Minister to supervise and ensure the safety of all registered dams and that owners are not in breach of their duty. As part of this role, the Minister has specific functions under the Act (Section 165C) which include:

- Maintaining a register of all dams

- Ensuring all dams comply with requisite standards of design, construction, maintenance and review as specified under the Regulations

- Obtaining information and keeping records on matters relating to the safety of dams.

Dam owners can be obligated to provide information on their dams either as a condition of a permit under Section 157 of the Act or from a direct order from the Minister under various other sections relating mainly to ongoing surveillance and maintenance (e.g. Sections 165F(2), 165H, 165J, 165L, 165M or $165 \mathrm{~N})$.

The Regulations 2003 for the most part provide prescribed standards for the competency of persons undertaking design, construction, maintenance and surveillance of dams, based on their hazard categories. The competency of such persons are classified as either 'any person', 'the owner', persons of either 'Class A', 'Class B' or 'Class C' competence, or an 'Expert Team'. Definitions of these classes of persons in Section 6 of the Regulations include:

- Class A - a professional engineer with relevant experience in the investigation, design, construction, and day-to-day safety management of dams of a height, type and hazard category similar to the relevant dam

- Class B - a professional engineer with relevant experience in dam technology appropriate to the relevant dam

- Class $\mathrm{C}$ - a professional technical specialist with relevant tertiary qualifications and relevant specialist experience in the investigation, design, construction or day-to-day safety management of dams of a height, type and hazard category similar to the relevant dam

- An Expert Team - at least one of the persons has Class B competence, and the persons collectively have a knowledge and understanding of the causes and modes of dam failure and also have professional expertise in the following areas in so far as they relate to the relevant dam and activity: engineering surveying, hydrology, hydraulics, engineering geology, soil and rock mechanics, properties of materials, dam design, structural and mechanical design.

Section 7 of the Regulations then provides for varying 'required competency standards' criteria based on the height of the dam, hazard category of the dam, and the type of activity/information to be undertaken/provided. An example of these criteria is provided in Table 3, which is applicable to dams up to $10 \mathrm{~m}$ in height. Other similar criteria are also provided in Section 7 of the Regulations for dams between $10 \mathrm{~m}$ and $25 \mathrm{~m}$ high, and for those greater than $25 \mathrm{~m}$ high. Section 9(1) of the Regulations requires that hazard categories be assessed in accordance with national guidelines published by ANCOLD (e.g. ANCOLD 2000a and 2000b). Similarly, all standards of design and safety management must comply with ANCOLD guidelines: this includes spillway design standards (ANCOLD, 2000b), the frequency and thoroughness of surveillance and review (ANCOLD, 2003) and any requirements for emergency action plans (ANCOLD, 2003). These guidelines are generally in line with international best-practice as determined by Pisaniello and McKay (1998) and Bradlow et al. (2002).

It is clear from Table 3 and Section 7 of the Regulations that the legislation in Tasmania encompasses all dams, large and small, low and greater hazard and clearly sets out the level of ongoing safety surveillance. DPIWE (2003) indicates that the owners of significant to high hazard dams are required to arrange safety inspections and reports by an experienced dam engineer after the initial filling of the reservoir and generally every 5 years during the life of the dam - for typical higher hazard irrigation dams in this category these reports can be expected to cost around AU\$2 000 (ZAR12 860). At the same time, in order to avoid placing significant cost burdens upon owners of smaller, less hazardous dams, these do not require full engineering reports; these reports may be prepared by the owner by completing a pro forma document supplied by the Department (DPIWE, 2003). DPIW have recognised that a cost-effective spillway design/review mechanism such as that reported in Pisaniello and McKay (2003 and 2005), if developed in Tasmania, would well complement this 'pro forma' process. Hence, DPIW in June 2008 commissioned the University of South Australia to undertake a pilot project to develop such technology in Tasmania. The results will be reported in a future paper.

There is no fee for registering dams. The policy looks to have all existing dams registered; any new dams are registered when they are granted a permit and the permit application fee covers this. The permit process for new dams is described in greater detail by DPIW (2008) and illustrated by IRIS Tasmania (2008). Fees for permits are set by the Water Management Regulations 1999 (per Schedule 4, Part 2). Current fees are: 381 fee units plus:

- 54 fee units for each hour spent in processing the application (excluding the first $7 \mathrm{~h}$ )

- 214 fee units where the application requires a notice under section 149 of the Act- most dam permits require advertising so this is the advertising cost

- 421 fee units where the assessment is made by the Assessment Committee.

Fee units are currently worth AU\$1.28 (ZAR8.23). It is important to note that applications for smaller, straightforward dams can be assessed by the Department under delegation from the Assessment Committee (IRIS Tasmania, 2008). This works well to minimise costs and fast-track these 'simpler' applications.

Regional Water Management Officers employed by the Department make the initial assessment of a dam's hazard when they do a field inspection of the proposed or existing dam site. This is then checked internally by the Department and if there is any doubt then a conservative approach is taken and/or the proponent is required to have the matter formally reviewed 


\begin{tabular}{|c|c|c|c|c|c|c|c|}
\hline \multicolumn{8}{|c|}{$\begin{array}{c}\text { TABLE } 3 \\
\text { Required competency standards under Tasmanian legislation for all dams up to } 10 \mathrm{~m} \text { in height } \\
\text { (Source: Water Management (Safety of Dams) Regulations 2003, Section 7) }\end{array}$} \\
\hline \multirow[t]{2}{*}{ Activity } & \multicolumn{7}{|c|}{ ANCOLD hazard category ${ }^{*}$} \\
\hline & Very low & Low & Significant & High C & High B & High A & Extreme \\
\hline $\begin{array}{l}\text { 1. Supervision of construc- } \\
\text { tion }\end{array}$ & Owner & Class A & Class A & Class A & $\begin{array}{c}\text { Expert } \\
\text { team }\end{array}$ & $\begin{array}{l}\text { Expert } \\
\text { team }\end{array}$ & $\begin{array}{l}\text { Expert } \\
\text { team }\end{array}$ \\
\hline $\begin{array}{l}\text { 2(a) Pre-construction inves- } \\
\text { tigation, design and report, } \\
\text { other than spillway design }\end{array}$ & Owner & Owner & $\begin{array}{c}\text { Class A and } \\
\text { Class C }\end{array}$ & $\begin{array}{l}\text { Class A } \\
\text { and } \\
\text { Class C }\end{array}$ & $\begin{array}{l}\text { Expert } \\
\text { team }\end{array}$ & $\begin{array}{l}\text { Expert } \\
\text { team }\end{array}$ & $\begin{array}{l}\text { Expert } \\
\text { team }\end{array}$ \\
\hline 2(b) Spillway design & Owner & Class A & $\begin{array}{c}\text { Class A and } \\
\text { Class C }\end{array}$ & $\begin{array}{l}\text { Class A } \\
\text { and } \\
\text { Class C }\end{array}$ & $\begin{array}{l}\text { Expert } \\
\text { team }\end{array}$ & $\begin{array}{l}\text { Expert } \\
\text { team }\end{array}$ & $\begin{array}{l}\text { Expert } \\
\text { team }\end{array}$ \\
\hline $\begin{array}{l}\text { 3. Design plans and specifica- } \\
\text { tions }\end{array}$ & $\begin{array}{c}\text { Any } \\
\text { person }\end{array}$ & Any person & Class A & Class A & $\begin{array}{c}\text { Expert } \\
\text { team }\end{array}$ & $\begin{array}{c}\text { Expert } \\
\text { team }\end{array}$ & $\begin{array}{l}\text { Expert } \\
\text { team }\end{array}$ \\
\hline $\begin{array}{l}\text { 4. Work-as-executed (WAE) } \\
\text { report }\end{array}$ & $\begin{array}{c}\text { Any } \\
\text { person }\end{array}$ & $\begin{array}{l}\text { (a) Class A, if the } \\
\text { dam is more than } 7 \mathrm{~m} \\
\text { high; or (b) Owner, if } \\
\text { the dam is not more } \\
\text { than } 7 \mathrm{~m} \text { high. } \\
\end{array}$ & Class A & Class A & $\begin{array}{l}\text { Expert } \\
\text { team }\end{array}$ & $\begin{array}{l}\text { Expert } \\
\text { team }\end{array}$ & $\begin{array}{l}\text { Expert } \\
\text { team }\end{array}$ \\
\hline $\begin{array}{l}\text { 5. Comprehensive or interme- } \\
\text { diate surveillance inspections } \\
\text { and reports }\end{array}$ & $\begin{array}{c}\text { Any } \\
\text { person }\end{array}$ & Owner & Class B & Class B & $\begin{array}{l}\text { Expert } \\
\text { team }\end{array}$ & $\begin{array}{l}\text { Expert } \\
\text { team }\end{array}$ & $\begin{array}{l}\text { Expert } \\
\text { team }\end{array}$ \\
\hline 6. Safety reviews & $\begin{array}{l}\text { Any } \\
\text { person }\end{array}$ & Class B & $\begin{array}{l}\text { Class B and } \\
\text { Class C }\end{array}$ & $\begin{array}{l}\text { Class B } \\
\text { and } \\
\text { Class C }\end{array}$ & $\begin{array}{l}\text { Expert } \\
\text { team }\end{array}$ & $\begin{array}{l}\text { Expert } \\
\text { team }\end{array}$ & $\begin{array}{l}\text { Expert } \\
\text { team }\end{array}$ \\
\hline $\begin{array}{l}\text { 7. Design and supervision of } \\
\text { decommissioning }\end{array}$ & $\begin{array}{c}\text { Any } \\
\text { person }\end{array}$ & $\begin{array}{l}\text { (a) Class B, if the } \\
\text { dam is more than } \\
7 \mathrm{~m} \text { high; or (b) } \\
\text { owner, if the dam is } \\
\text { not more than } 7 \mathrm{~m} \\
\text { high }\end{array}$ & Class B & Class B & Class B & Class B & Class B \\
\hline
\end{tabular}

*ANCOLD (2000a and 2000b) provides further details on these hazard classifications

by an engineer. A dam's hazard potential will then determine the Department's mandates as to the frequency of surveillance inspections, reports, safety reviews, and emergency action plans in line mainly with ANCOLD's Guidelines on Dam Safety Management (2003).

The Water Management (Safety of Dams) Regulations 2003, Section 13(1) also requires that dam owners pay a fee to the Crown for assessing design, construction, maintenance, surveillance or decommissioning reports in respect of one or more dams as follows: 25 fee units for the first dam; and 20 fee units for each $0.5 \mathrm{~h}$ spent in assessing the report - but not exceeding a total of 250 fee units. This, together with the incremental fee structure for permits outlined above, provides an innovative and equitable user-pays type method for subsidising the dam- safety assurance policy in Tasmania.

Monetary penalties are provided for under the Act and attach to any person failing to comply with any provisions of the Act or orders made under the Act. For example, a maximum fine of 100 penalty units applies to any person failing to provide information to the Minister on the safety of their dam under Section $165 \mathrm{H}$, and a maximum fine of 200 penalty units and a daily fine not exceeding 20 penalty units (for each day during which the offence continues) attaches to any person failing to comply with a maintenance order under Section 165L. Body corporates attract fines 2.5 times these levels. Penalty units are currently worth AU\$120 (ZAR772). These are serious penalties and are in line with international best practice as identified by Pisaniello and McKay (1998).

Finally, the Department provides for substantial owner education and guidance through the publication of website information and articles in Departmental and other publications, see for example DPIWE (2003), DPIW (2007) and DPIW (2008).

\section{How the policy is progressing - Feedback from key policy actors}

DPIWE (2005) reported that implementation of dam-safety legislation and regulations following amendment to the Act in 2002 now ensure that best practice safety procedures are followed in the construction, maintenance and surveillance of dams in Tasmania.

As of 2005, there were 5674 registered dams in Tasmania (DPIWE, 2005). Currently there are around 8000 (Ditchfield, 2008). This increase is due to the new dams (around 200 per year) that have been built since 2005 as well as many existing dams having been identified and registered for the first time - evidence that the policy is being administered effectively. Around 500 of the registered dams are of either significant hazard or higher (Ditchfield, 2008), i.e. being sufficiently hazardous to require extensive ongoing statutory safety surveillance and reporting. All of these dams have been placed on a 'prescribed dams' register within the DPIW dam database. Around $66 \%$ of the prescribed dams are privately owned. From 2003 to 
2005, 218 notices had been sent requiring prescribed dam owners to undertake a dam-safety surveillance inspection (DPIWE, 2005). In 2008, a further 350 prescribed dam notices will be sent requiring hazard rating review, surveillance and inspection (Ditchfield, 2008)

The progress of the Tasmanian policy and the problems identified by this paper were formally discussed with the Water Management Group of the Department of Primary Industries and Water (DPIW) in Tasmania in October 2007 and again in June 2008. The Group reported that it is taking considerable time, effort and resources for DPIW to identify all existing dams in Tasmania that should be included on the register, and to ensure that they comply with the damsafety legislation. Unfortunately resources to DPIW for this purpose are limited, so significant and high-hazard dams are currently being given priority in terms of strict enforcement of requisite safety and surveillance standards. Nevertheless, even low-hazard dams are targeted whenever a potential cascade failure scenario arises. Such scenarios are common throughout the State. DPIW gives careful consideration to these scenarios and does upgrade the hazard rating of smaller dams to a higher level, when appropriate, so that stronger surveillance, reporting and safety standards are imposed. For the many other lower-hazard dams in the State, DPIW have indicated that these will eventually all be identified using field surveillance officers, satellite imagery and other mapping techniques, and entered onto the register. The 5-yearly surveillance reports mandated by the dam-safety regulations will then also be strictly imposed on these dams. Inevitably, as all dams throughout Tasmania are discovered and come onto the register, the cumulative threats posed by small dams in catchments will be minimised in the State.

\section{Summary and discussion}

There is a clear need in areas where potentially hazardous private dams exist to ensure that owners review and maintain their dams in line with current acceptable practice and take appropriate remedial action where necessary. Adequate assurance can only be provided through the implementation of appropriate policy which requires the backing of legislation. The experience of NSW demonstrates that dam-safety programs are workable and not too costly as the NSW Dams Safety Committee operates on a small annual budget of around AU\$1 000000 (ZAR6 430 000). Elements of best practice can and do exist successfully to control the safety management of private dams and in turn provide increased dam-safety assurance to the public and promote the ideals of reducing loss of life as well as environmental and economic losses. The results of the NSW 'supervised dams' case study presented here clearly shows this.

However, the policy must also be extensive enough to ensure that all potentially hazardous dams are supervised: this usually means that adequate funding must be made available for complete administration of the policy, and for an adequate register of all dams to be maintained. For example, in NSW additional government funding and some form of user pays principle may be required if the safety committee extended its remit: the 'non-supervised dams' case study reported here demonstrates this need. Tasmania provides an innovative and equitable user-pays method for helping government to subsidise dams safety assurance policy, and sets a good example for other jurisdictions to follow.

While NSW has strong dam-safety assurance policy in place, and other mainland states have made good positive in-roads (e.g. Queensland and Victoria), each mainland State also needs to address the considerable risks associated with cumulative failure of small dams. Most small dams individually pose only a minimal hazard, but when considered cumulatively in a catchment above, say, a large hazardous public dam, they can pose significant risk to premature breach of the public dam, and in turn, extremely serious consequences further downstream. Maintaining an adequate register of all dams, large or small, high or lower hazard provides a mechanism for having some control over the spillway capacities of the multitude of small dams that may exist in a jurisdiction. Further research is needed to critically determine whether all such small dams should be designed to the same high hazard category standard of the end-of-line dam and in what circumstances. However, it has been made clear that they should be mandated, as a bare minimum, to meet the ANCOLD fall-back spillway design standard for low-hazard dams (i.e. 1 in 100 to 1 in 1000 years design flood).

In this respect, Tasmania provides the 'model' on how this can be best achieved. The Tasmanian approach is in line with international best-practice dam-safety assurance policy, and is the only State in Australia thus far to acknowledge that even small, low-hazard dams need to be supervised, albeit to a modest extent. Cost burdens to small-dam owners can also be minimised by making available affordable design/review processes such as the simple pro-forma used in Tasmania and the cost-effective flood capability design/review procedure used here in the NSW case studies. This is a good way that governments can ensure that not only the larger potentially hazardous dams are kept safe, but also the cumulative safety threats posed by small dams are kept in check.

\section{Conclusion}

At an international level, much attention is being devoted to the safety of medium to large-scale dams. This paper has established a clear need to also address the serious potential problems associated with smaller dams, particularly the potential cumulative safety threats they pose in catchments. This need is supported by both past experience with bad cumulative style dam failures in a number of countries, and by recent research in South Australia into this novel area of cumulative risk.

Different jurisdictions attempt to tackle dam safety at different levels. But even the strongest of dam safety policy can fall short when it comes to managing the very real safety threats associated with populations of small dams at the cumulative level. The NSW case-study results have demonstrated this and provided valuable lessons. For example, the importance of registering all dams and the need for some form of supervision of even small dams due to either their individual or cumulative hazard potential. The State of Tasmania has provided a 'model' on how this can be best achieved in line with international best-practice.

The lessons in this paper can provide guidance to any jurisdiction in Australia and abroad that has populations of small dams in catchments posing either individual or cumulative safety threats to downstream communities, as well as guidance to implement policy that achieves better management of small dams for sustainable and safe catchments.

\section{Acknowledgements}

The author wishes to acknowledge the Department of Primary Industries and Water Tasmania, and especially Mr Sam 
Ditchfield, Mr Ludovic Schmidt and Dr Alan Harradine for providing information on the Tasmanian Dams Safety Policy and its progress. Special thanks to the Dams Safety Committee in NSW, and in particular Mr Norm Himsley and Mr Michael Karp for their assistance with the dam-safety testing of the DSC-supervised dams and the provision of valuable information. The author also wishes to acknowledge the Australian Research Council (ARC) for Discovery Project funding to undertake the NSW research reported here, and also for a second round of Discovery Project funding from 2009-2011 to further research this novel topic of cumulative catchment threats. From the University of South Australia, appreciation goes to Prof Jennifer McKay of the Centre for Comparative Water Policies and Laws for her involvement in the previous ARC Discovery Project, and to Mr Arthur Spassis for his valuable research assistance throughout. Many thanks also to Prof Roger Burritt from the Centre for Accounting, Governance and Sustainability at UniSA for his recent interest in and support of the 'cumulative threats' research.

\section{References}

ANCOLD (1992) Status of dam safety in Australia. ANCOLD Bull. No. 91, Australian National Committee on Large Dams. 9-29.

ANCOLD (1995) Draft Guidelines on Design Floods for Dams, Australian National Committee on Large Dams, October 1995.

ANCOLD (2000a) Guidelines on Assessment of the Consequences of Dam Failure, Australian National Committee on Large Dams.

ANCOLD (2000b) Guidelines on Selection of Acceptable Flood Capacity for Dams. Australian National Committee on Large Dams.

ANCOLD (2003) Guidelines on Dam Safety Management, Australian National Committee on Large Dams.

BC TONKIN \& ASSOCIATES (1997) Happy Valley Reservoir Extreme Flood Hydrology Study, A Technical Report. Ref. No. 95.0296. Prepared for the SA Water Corporation of the South Australian Government, SA Water, Adelaide, Feb 1997.

BRADLOW DD, PALMIERI A and SALMON SMA (2002) Regulatory Frameworks for Dam Safety - A Comparative Study. The World Bank, Law Justice and Development Series, Washington DC.

DAMS SAFETY ACT 1978 (NSW) Parliament of New South Wales, Sydney, Australia.

DANIELL T and HILL P (1993) Flood Hydrology Study of the Onkaparinga River. Technical Report produced in The University of Adelaide through Luminus (Pty) Ltd for The Onkaparinga Flood Study Steering Committee, Adelaide, Australia.

DITCHFIELD S (2008) Personal communication. Dams Safety Engineer, Dept of Primary Industries and Water, Tasmania, June 2008

DPIWE (2003) Making dams safe for everyone. Published in a quarterly periodical produced by Dept of Primary Industries, Water and Environment, Tasmania, entitled Tas-Regions 9 (1) 16-17.

DPIWE (2005) Report on the Operation of the Water Management Act 1999, Dept of Primary Industries, Water and Environment, Tasmania. Report by Water Resources Division. May 2005.

DPIW (2007) Dam Works Code 2007. Dept of Primary Industries and Water, Tasmania, August 2007.

DPIW (2008) Dam Construction Permits, Website of the Dept of Primary Industries and Water, Tasmania. URL: www.dpiw.tas.gov.au/ inter.nsf/WebPages/RPIO-4YG57U?open (Accessed 31 July 2008).

ENGELS J (2005) Stava tailings dam failure near Trento Italy.

URL: www.tailings.info/stava.htm (Accessed 3 June 2005).

FOSTER M, FELL R and SPANNAGLE M (2000) The statistics of embankment dam failures and accidents. J. Can. Geotech. 37 (5) 1000-1024.

GRAHAM WJ (1999) A Procedure for Estimating Loss of Life Caused by Dam Failure. United States Dept of Interior, Bureau of Reclamation, Dam Safety Office, Report DSO-99-06, Denver, Colorado.
HARRISON JF (1992) Central Hills Region Councils-Study of Flooding on the $30^{\text {th }}$ August, 1992 and $8^{\text {th }}$ October 1992. SA Govt Report. District Council of Stirling, South Australia, October, 1992. 1-15.

HISER W and McDONALD L (1989) Dam safety. Proc. Conf. Water Supply and Resources. Nov. 1988, Sydney, NSW. 163-171.

IRIS TASMANIA (2008) Dam Permit Approval. Information website of the Tasmanian State Government.

URL: www.iris.tas.gov.au/planning and development/charts/dam permit (Accessed 31 July 2008).

IEAUST (1999) Australian Rainfall and Runoff - A Guide to Flood Estimation. Institution of Engineers, Australia, Canberra.

KAZAROVSKI P (1996) Farm dams do not have impact on large floods or do they? Proc. 23 ${ }^{\text {rd }}$ Hydrology and Water Resources Symp. 21-24 May, Hobart, Australia. 725-726.

LANGE DAMES CAMPBELL (SA) (Pty.) Ltd. and Snowy Mountains Engineering Corporation (LDC and SMEC) (1995) River Torrens Flood Hydrology Study. A Technical Report for SA Government Engineering \& Water Supply Department, Ref. No. SA485 (2 volumes). 2-3, 40 and 43.

LEWIS B and HARRISON J (2002) Risk and consequences of farm dam failure. Proc. 27 $7^{\text {th }}$ Hydrology and Water Resources Symp. Institution of Engineers Australia, May 2002, Melbourne, Australia.

McKAY J (2001) The modern Australian history of corporatisation and privatisation of water supplies and irrigation - lessons for the regulators. In: Water History - Lessons for the Future. Hydrological Society of South Australia Inc, Institution of Engineers, Stormwater Industry Association, History Trust of SA. 87-97.

McKAY J and PISANIELLO JD (1995) What must the reasonable private dam owner foresee? Aust. J. Disaster Manage. - The Macedon Digest. 9 (4) 27-28.

MURLEY K (1987) Referable dams in Victoria - Spillway inadequacy. ANCOLD Bull. No. 76, April 1987. 24-26.

NSW Department of Land and Water Conservation (1995) Pindari Dam, Fact Sheet.

NSW DSC (1993) Information Sheet 2 - Role Policy and Procedures, NSW Dams Safety Committee, Library of Information Sheets.

NSW DSC (2003) Annual Report for 2002/03, NSW Dams Safety Committee.

NSW DSC (2007) Annual Report for 2006/07, NSW Dams Safety Committee.

PISANIELLO JD (1997) Analysis and Modelling of Private Dam Safety Assurance Policy and Flood Capability Design/Review Procedures. Ph.D. Thesis, University of South Australia.

PISANIELLO JD and McKAY JM (1998) Models of appropriate practice in private dam safety assurance. Water Policy 1 (5) 525-550.

PISANIELLO JD, ARGUE JR and McKAY JM (1999) Flood capability design/review of dams on small catchments - a simple and cost-effective regionalised procedure. Aust. J. Water Resour. 3 (2) 177-188.

PISANIELLO JD and McKAY JM (2003) A farmer-friendly dam safety evaluation procedure as a key part of modern Australian water laws. Water Int. 28 (1) 90-102.

PISANIELLO JD and McKAY JM (2004) Spillway Design and Review Procedures for Australian Farm Dams. Rural Industries Research and Development Corporation (RIRDC), Ref No. 04/051, ISBN No. 0642587612, ISSN No. 1440-6845, Australian Government, Canberra.

PISANIELLO JD and McKAY JM (2005) Australian community responses to upgraded farm dam laws and cost-effective spillway modelling. Int. J. Water Resour. Dev. 21 (2) 325-340.

PRICE J, LEWIS B and RUTHERFURD I (2003) Water quality in small farm dams. Proc $28^{\text {th }}$ Int. Hydrol. Water Resour. Symp. 10-14 Nov 2003, Wollongong, NSW. Institution of Engineers Australia.

SI Y and QUING D (1998) The world's most catastrophic dam failures: The August 1975 collapse of the Banqiao and Shimantan dams. In: Thibodeau JG and Williams PB (eds.) The River Dragon Has Come! The Three Gorges Dam and the Fate of China's Yangtze River and its People (Chapter 3). Probe International and International Rivers Network, M.E. Sharpe, Armonk, New York. 
UN IPCC (2007) Summary for policy makers. In: Solomon S, Qin D, Manning M, Chen Z, Marquis M, Averyt KB, Tignor M and Miller HL (eds.) Climate Change 2007:The Physical Science Basis, Contribution of Working Group 1 to the Fourth Assessment Report of the United Nations Intergovernmental Panel on Climate Change. Cambridge University Press, Cambridge, United Kingdom and New York, NY, USA.

WATER ACT 1989 (VIC), Parliament of Victoria, Melbourne, Australia.
WATER ACT 2000 (QLD), Parliament of Queensland, Brisbane, Australia.

WATER MANAGEMENT ACT 1999 (TAS), Parliament of Tasmania, Hobart, Australia.

WATER MANAGEMENT REGULATIONS 1999 (TAS), Parliament of Tasmania, Hobart, Australia.

WATER MANAGEMENT (SAFETY OF DAMS) REGULATIONS 2003 (TAS), Parliament of Tasmania, Hobart, Australia. 